Lidia Grzybowska ๑ https://orcid.org/0000-0003-4782-8457

Jagiellonian University in Kraków

lidia.grzybowska[at]uj.edu.pl

\title{
Arbor Praedicandi. Some Remarks on Dispositio in Mediaeval Sermons (on the Example of Sermo 39 "Semen Est Verbum Dei" by Mikołaj of Błonie)*
}

\begin{abstract}
The main aim of this paper is to present the motif of a tree-shaped compositional scheme called arbor picta (arbor praedicandi) and to show it against the field of rhetorical elements such as dispositio and memoria as found in mediaeval sermons. The basic sources for the analysis of this question are two fourteenth-century theoretical treatises on the art of preaching (manuals: Libellus artis preadicatorie by Jacobus de Fusignano and Tractatulus solennis de arte et vero modo praedicandi by Pseudo-Thomas Aquinas), and one of the sermons from the collection de tempore of a fifteenth-century Polish preacher, Mikołaj of Błonie (Dominica sexagesime: sermo 39 "Semen est verbum Dei"). The problems of arbor praedicandi, which are part of a broader field of study on the structure of sermons, editorial methods of texts and mnemonics, were the subject of interest of many researchers such as H. Caplan, O.A. Dieter, S. Khan, S. Wenzel. In Poland, this issue has not yet become a subject of proper study.
\end{abstract}

* The study is the result of research project No UM2013/11/N/ HS2/03506 funded by the National Science Centre. Polish text: L. Grzybowska, "Arbor praedicandi. Kilka uwag o dispositio w kazaniach średniowiecznych (na przykładzie sermo 39 «Semen est verbum Dei» Mikołaja z Błonia)," Terminus 3/ 16 (2014), pp. 259-283. 
In order to analyse this scheme in the treatises of Jacobus de Fusignano and Pseudo-Thomas Aquinas, as well as in the exemplary sermon, the paper briefly outlines the existence of topics and images of the tree in the writings of the Middle Ages (e.g. lignum vitae, arbor sapientiae, arbor amoris). Then fragments from the manuals of Jacobus de Fusignano and Pseudo-Thomas Aquinas are presented in which the authors discussed the scheme in question and explained its importance for the practice of preaching. An analysis of a practical example-here: sermo 39 from Mikołaj of Błonie's collection de tempore-shows the creative use of the tree scheme in the sermon by the Polish preacher (with the speculative assumption that Mikołaj of Błonie knew Jacobus's theory of preaching). Particular attention is also paid to the circumstances of the development of the art of preaching in the late Middle Ages in Poland. Finally, the importance of the concept of the sermon as a tree for the elements of rhetoric such as dispositio/divisio/partito and memoria is emphasised. In this study, it is shown that the use of the tree scheme in presenting abstract concepts and structuring texts allowed preachers and their audiences to visualise vague and often difficult ideas, as well as to describe their relationship within the subjects of the sermons. Therefore, the use of the scheme in the Middle Ages had great significance for ars memorativa and the didactic dimensions.

Keywords: arbor picta, arbor praedicandi, ars praedicandi, late-mediaeval preaching

\begin{abstract}
Predicare est arborisare - this saying, the origin of which is attributed to Jacobus de Fusignano ${ }^{1}$ or to the fifteenth-century preacher Maurice of Leiden, ${ }^{2}$ sets the thematic horizon of this paper. It is an attempt to outline the rhetorical concept of "sermon as a tree," popular in the late Middle Ages, which is located on the borderline of questions concerning text structure and editorial issues, as well as mnemonic techniques. It was the subject of deliberations conducted by preaching theoreticians and a source of inspiration for active preachers in the fourteenth and fifteenth centuries.
\end{abstract}

1 See F. R. de la Flor, "El diagrama: geometría y lógica en la literatura espiritual del Siglo de Oro", in Estado actual de los estudios sobre el Siglo de Oro, ed. M. García Martín, Salamanca 1983, p. 841.

2 See D. Roth, Die mittelalterliche Predigttheorie und das Manuale Curatorum des Johann Urlich Surgant, Basel 1956, pp. 128-130. 
This paper aims to briefly present the areas of mediaeval knowledge and culture in which the tree scheme was used, and then the propaedeutic characteristics of two treatises on preaching, in which the concept of "sermon as a tree" was used. These two treatises are Libellus artis preadicatorie of Jacobus de Fusignano and Tractatulus solennis de arte et vero modo predicandi by Pseudo-Thomas Aquinas. The echoes of the recommendations presented in these textbooks can be seen in the way sermons in Poland were prepared, which is why an analysis of an exemplary sermon will also be presented. This will be sermo 39 "Semen est verbum Dei" by Mikołaj of Błonie (also known as Mikołaj Pszczółka). My aim is to observe the relationship between the rules proclaimed by the codifiers of the art of preaching and the practical implementation of these recommendations in late-mediaeval Poland. Finally, I will try to answer the question concerning the importance of the concept of the sermon as a tree for rhetorical elements such as dispositio/divisio/partito and memoria.

The image of a tree was a handy multifaceted figure of thoughts. It could function as a metaphor, metonymy, allegory, or a symbol through which specific ideas and meanings were conveyed. ${ }^{3}$ In the Judaeo-Christian culture, the motif of a tree has a special meaning. It appears in the Bible many times and carries various meanings, including the most important one, which is the tree of life (lignum vitae). From this point of view, a tree can be understood as a symbol of the beginning of human history. The tree of knowledge of good and evil initiates and seals the fate of man. In Christian soteriology, a tree becomes the beginning of a new history of humanity - the tree of the cross,

3 About the significance of tree symbolism in religions see, amongst others, N. Smith, P. L. R. Smith, and H. Luckett, “The tree in world mythologies”, in The Tree of Life: New Images of an Ancient Symbol, London 1989; E. O. James, "The tree of life, studies in the history of religions", Supplements to Numen 11 (1966); G. Widengren, The King and the Tree of Life in Ancient Near Eastern Religion, Uppsala 1951. 
on the one hand, marks the end of a certain stage and, on the other, opens up a completely new dimension of human life on earth. This was clear to Christian artists, who often looked for a direct, unprefigured relationship between the paradise tree and the material of the cross (hence the motif, popular in the Middle Ages, which concerns the origin of the wood from which Christ's cross was made-it was claimed that the material was the tree from Eden ${ }^{4}$ ). Both in the Old and the New Testament, the motif of a tree appears many times as a means to convey various ideas, from genealogical (the stem of Jesse, Isaiah 11:1) to apocalyptic (the tree of life, the Apocalypse of St John 22:2), to prophetic (King Nebuchadnezzar's dream, Daniel 4:1-24).

In the Middle Ages, the scheme or image of a tree was used in many ways. Inspiration was sought not only in the biblical examples mentioned above or the popular Platonic dialogue Timaeus (in which there is an image of a man as an inverted tree with hair as roots and legs as branches). Patterns were drawn primarily from the observation of everyday life. From the thirteenth century onwards, almost every concept, every idea could be adapted to the structure of the tree. The peak of its popularity came in the early printing period. ${ }^{5}$ The tree scheme made it possible to organise thoughts, to show interlinkages

4 Arbor crucis is one of the most frequently used motifs in religious poetry and Passion sermons throughout the Middle Ages (e.g. Carmen de pascha by St Cyprian, the hymn Vexilia regis prodeunt by Venantius Fortunatus, Carmen de laudibus sanctae crucis by Rabanus Maurus, or the homily of Peter Damian entitled De exaltatione sanctae crucis). In Polish literature, attention is drawn, for example, to the Miraculous History of the Creation of Heaven and Earth by Krzysztof Pussman (K. Pussman, "Historia barzo cudna o stworzeniu nieba i ziemie", in Caly świat nie pomieściłby ksiag. Staropolskie opowieści i przekazy apokryficzne, ed. W. R. Rzepka and W. Wydra, Ed. $2^{\text {nd }}$, Warsaw 2008, pp. 91-104).

5 C. Klapish Zuber, "The tree", in Finding Europe: Discourses on Margins, Communities, Images $\mathrm{Ca} .13^{\text {th }}-\mathrm{Ca}$. $18^{\text {th }}$ Centuries, ed. A. Molho, D. Ramada Curto, and N. Koniordos, Oxford-New York 2007, p. 297; A. R. Verboon, Lines of Thoughts: Diagrammatic Representation and the Scientific Texts of the Arts Faculty 1200-1500, Universiteit Leiden 2010 (doctoral thesis). 
in a discussed question and to put them in a proper hierarchy, which was particularly suitable for presenting the dependencies that connect scholastic formulas and theories.

The motif of a tree was used mainly as lignum vitae and was explored in various ways by visual artists, as well as in poetry, theological, dogmatic, and mystical reflections. It was made popular by St Bonaventure's Lignum Vitae. ${ }^{6}$ Its religious dimension, through which it is part of the history of salvation, was not the only one. It was also a way of presenting a complex problem in a schematic way that appealed to the imagination, as in the case of the tree of Jesse. The image of a tree evokes both growth (i.e. development), division, symmetry, and mutual relations. Therefore, it became such a handy figure of thought, which aided the explanation of various connections and allowed for the metaphorical expression of ideas. The tree scheme facilitated the presentation of various divisions and systematisations. Stemmata, that is genealogical charts known at least since Roman times, used the image of a tree to show family relationships and dependencies. In the Middle Ages, this schematic was often used in the conceptualistic representation of complex issues from various fields, thus functioning as an inexhaustible rhetorical figure. For example, the following treatises can be mentioned: Arbor amoris of Pseudo-Bonaventure (1 $14^{\text {th }}-15^{\text {th }}$ century), anonymous Arbor virtutum, Arbor vitiorum, Arbor amoris, Arbor vitae, Arbor sapientiae, Arbor passionis domini, as well as Arabic works (for example, the short treatise Shajarat al-Kawn by Ibn al'Arabi, 1165-1240, whose main theme is the tree of creation and which had a significant influence on Christian thought), or cabbalistic works (for example, Sefer ha-Zohar probably by Moses ben Shem-tob de León, c. 1250-1305). ${ }^{7}$ We should also mention artistic

6 P. F. O'Connell, The "Lignum Vitae" of Saint Bonaventure and the Medieval Devotional Tradition (Spirituality, Franciscans), ETD Collection for Fordham University, 1985.

7 C. Robinson, "Trees of love, trees of knowledge: Toward the definition of a cross-confessional current in late medieval Iberian spirituality, Medieval Encounters 3 (2006), p. 397. 
representations, such as the painting by Pacino di Buonaguida Albero Della Vita, connected with Franciscan spirituality (e.g. with the Lignum Vitae of St Bonaventure and the work of Ubertino of Casale, 1259-c. 1329, Arbor Vitae Crucifixae Jesu Christi). The tree scheme was often used to present the division of academic disciplines (cf. Expositio prologi Bibliae by Henry of Langenstein, ${ }^{8}$ died 1397) and was frequently used as a way of comparing the degrees of the mystical ascent to God with the branches of a symbolic palm tree (Palma contemplationis, ${ }^{9}$ c. 1217-1245).

Particularly noteworthy is the work of one of the most interesting and quite eccentric figures of the Middle Ages, Ramon Llull ${ }^{10}$ (1232-1316). This extremely hardworking and prolific author left behind many works in which he used the image of a tree to present various philosophical issues. In one of his most famous treatises, Arbor scientiae (Arbre de ciencia, 1296), he used the tree as a symbol of the gradually growing participation in the divine, which is the only possible way of entering into a union between God and his creation. In this way, he transferred the image of a tree from the field of logical schemes, which help to arrange thoughts and indicate causal links, to the field of purely ontological considerations.

8 N. H. Stenck, “A late medieval arbor scientiarum”, Speculum 2/50 (1975), pp. 245-269.

9 Н. А. Бондарко, “Трактат о пальме. Композиционная форма и богословский смысл”, Начало. Журнал института богословия и философии 9 (2000), pp. 139-153.

10 From the rich literature on Ramon Llull, the following deserve attention: J. M. Ruiz Simón, L’Art de Raimundo Lulio i la teoría escolàstica de la ciència, Barcelona 1999; J. P. Pastor, "La mística Luliana : pretensión de síntesis", Taula: quaderns de pensament 37 (2002), pp. 73-82; P.A. Bonner, The Art and Logic of Ramon Llull, Brill 2007; Los Mundos de Ramón Llull, ed. J. Butiñá Jiménez, Madrid 2012. Many valuable studies can be found at www.ramonllull.net (accessed on 16 Feb. 2014) and www.quiestllullus.narpan.net (accessed on 18 Feb 2014). 
The vivid comparison of sermon composition to the structure of a tree is called arbor picta. This name is taken from the late-mediaeval codex (no. 23865) kept in the Bayerische Staatsbibliothek in Munich. ${ }^{11}$ It is a page containing Arbor de arte sive modo praedicandi, i.e. a drawing probably used for educational purposes that shows the composition of a sermon inscribed in the tree schematic. A copy of the page was included by Harry Caplan in his paper A Late Medieval Tractate of Preaching, ${ }^{12}$ which contains a translation of the treatise on the art of preaching by Pseudo-Thomas Aquinas. Three similar reproductions have been included in Otto A. Dieter's Arbor Picta: The Medieval Tree of Preaching, one of the few studies devoted entirely to the question of arbor picta. ${ }^{13}$ Floyd Douglas Anderson ${ }^{14}$ and Sarah Khan ${ }^{15}$ have also studied this issue. Marginal remarks on this subject can also be found in Siegfried Wenzel's short afterword to the edition of five mediaeval treatises on preaching, ${ }^{16}$ as well as in Alaister Minnis' chapter in Medieval Imagination and Memory. ${ }^{17}$ What is more, several symposia and lectures, including the session The Tree as Symbol,

11 F. 19 Arbor picta de arte praedicandi, in Catalogus codicum latinorum Bibliothecae Regiae Monacensis, ed. C. Halm and G. Meyer, vol. 4, part 4, Munich 1881, http://daten.digitalesammlungen.de/ db/ bsb00008255/images/index.html?fip=19 3.174.98.30\&seite $=109 \&$ pdfseitex $=($ accessed on 7 June 2014 $)$.

12 H. Caplan, "A late mediaeval tractate on preaching", in H. Caplan, Of Eloquence. Studies in Ancient and Mediaeval Rhetoric, 1970, pp. 40-78.

13 O. A. Dieter, “Arbor Picta. The medieval tree of preaching”, Quarterly Journal of Speech 51 (1965), pp. 123-144.

14 F. D. Anderson, "Dispositio in the preaching of Hugh Latimer", Speech Monographs 35 (1968), pp. 452-454.

15 S. Khan, Diversa Diversis. Mittelalterliche Standespredigten Und Ihre Visualisierung, Köln 2007.

16 S. Wenzel, The Art of Preaching. Five Medieval Texts and Translations, Washington D.C. 2013.

17 A. Minnis, "Medieval imagination and memory", in The Cambridge History of Literary Criticism, vol. 2: Middle Ages, ed. A. Minnis and I. Johnson, Cambridge 2005, pp. 239-274. 
Allegory, and Structural Device in Medieval Art and Thought at the International Mediaeval Congress 2008 were devoted to the question of tree symbolism in the Middle Ages. One of the most recent studies on this subject is The Tree: Symbol, Allegory, and Mnemonic Device in Medieval Art and Thought edited by Pippa Salonius and Andrea Worm (Brepols 2014). In Polish literature, Krzysztof Bracha made an important, though small, reference in his work on the collection of Piotr of Miłosław. ${ }^{18}$

These studies focus on two treatises on the art of preaching - the textbooks of Jacobus de Fusignano and Pseudo-Thomas Aquinas. In the first half of the fifteenth century in Poland the following works on the subject were known (from about 240 manuscripts scattered around European libraries): Ars praedicandi by John of Wales, Ars sermocinandi by St Bonaventure, De eruditione praedicatorum by Humbert de Romans, Rhetorica divina sive ars oratoria eloquentiae divinae by William of Auvergne, Ars praedicandi by Henry of Langenstein, De arte componendi sermones by Astasius, Notabilia circa modum praedicandi et cautele praedicatorum by an anonymous author, Ars sermocinandi by Landulf, De modo componendi sermones cum documentis by Thomas Waleys, Ars sermocinandi by Thomas de Tuderto, Tractatus et ars de modo praedicandi by Alfons de Alprão, Ars praedicandi populo by Francesc Eiximenis, Ars brevis et clara faciendi sermones secundum formam silogisticam by Jean de Chalôns, the anonymous De forma praedicandi (inc. Predicator ut habeat formam praedicandi studeat), and De praedicatione autoritates pertum, as well as Regula pastoralis by Pope Gregory I and De doctrina Christiana by St Augustine. ${ }^{19}$ The textbook by Jacobus de Fusignano was known in

18 K. Bracha, Nauczanie kaznodziejskie w Polsce późnego średniowiecza. „Sermones dominicales et festivales” $z$ tzw. kolekcji Piotra $z$ Miłosławia, Kielce 2007, p. 92.

19 Cf. e.g: R. M. Zawadzki, Spuścizna pisarska Stanisława ze Skarbimierza. Studium źródłoznawcze, Cracow 1979, pp. 131-140; B. Chmielowska, "Ars praedicandi Stanisława ze Skarbimierza”, in Retoryka w XV stuleciu. Studia nad tradycjami, teoriq i praktyka retoryki piętnastowiecznej, ed. M. FrankowskaTerlecka, Wrocław 1988, 
the Prague intellectual circles. ${ }^{20}$ Stanisław of Skarbimierz probably became acquainted with it during his studies in that city. Perhaps thanks to him, the textbook reached Cracow, where it survived in two manuscripts (BJ 2014, ff. 330v-362v, BJ 2151, ff. 1-13v). ${ }^{21}$ Little is known about the Polish reception of the treatise by Pseudo-Thomas Aquinas, but since his ideas coincide with the theories contained in Jacobus's work (Pseudo-Thomas's textbook is considered a summary of Jacobus's text), we should briefly present its assumptions as well.

\section{(a) Libellus artis praedicatorie by Jacobus de Fusignano}

Jacobus de Fusignano ${ }^{22}$ was an Italian Dominican who held many different ecclesiastical functions, such as the Prior of Santa Maria sopra Minerva in Rome, the Second Provincial Prior of the New Province of the Kingdom of Sicily, the Chaplain Consiliarius et familiaris of King Charles II of Anjou, and the Bishop of Lucerne. He became famous as an excellent preacher, and in 1288 he received the title of Generalis Praedicator, the best preacher of the Roman province of Lucca. He died around 1333 as Bishop of Methone. Only two of the few writings attributed to him seem to be actually authored by him, namely a theological treatise in which he took a stance on the controversy surrounding Christ's poverty (Responsio et dicta de paupertate Christi, also entitled De paupertate Christi et apostolorum), and a textbook on the art of preaching, known as Libellus artis praedicatorie. The latter,

pp. 121-135; T. Michałowska, Średniowieczna teoria literatury w Polsce. Rekonesans, Wrocław 2007, pp. 205-208.

20 Zawadzki, Spuścizna.

21 Ibid.

22 Sources for the biography of Jacobus de Fusignano: T. Käpelli, "Jacobus de Fusignano OP (†1333)”, Archivum Fratrum Praedicatorum, 15 (1945), pp. 134-142; S. Hallik, Sententia und proverbium, Begriffsgeschichte und Texttheorie in Antike und Mittelalter, Köln 2007, pp. 346-349; Wenzel, The Art; Roth, Die mittelalterliche Predigttheorie; in Polish literature on the subject, e.g. Michałowska, Sredniowieczna. and-in the context of the predicatory output of Stanisław of Skarbimierz-Chmielowska, "Ars praedicandi"; Zawadzki, Spuścizna. 
written probably around 1310, was very popular in the fourteenth and fifteenth centuries. ${ }^{23}$ Preserved in more than twenty manuscripts throughout Europe and in several incunabula editions as an addition to the pastoral textbook by Guido de Monte Rocherii entitled Manipulus curatorum written in 1333, it had a significant influence on preaching at the close of the Middle Ages. It provides a comprehensive overview of the issues connected with the art of preaching, with particular emphasis on the issues of invention, disposition, and elocution. There is little space devoted to the art of remembering (memoria) and delivering (pronuntiatio, actio) sermons to the listeners. The advantages of the textbook included the simple language of the lecture and the numerous examples used by the author to illustrate the theory. The treatise was not revolutionary but presented modern ways of preparing sermons from a scholastic perspective.

The textbook consists of nineteen chapters. It opens with a quote from St Paul's letter to Philippians: "And this is my prayer: that your love may abound more and more in knowledge and depth of insight so that you may be able to discern what is best and may be pure and blameless for the day of Christ" (Phil 1:9-10, New International Bible). Then, referring to the findings of Aristotle, which were inspirations for other authors of artes praedicandi, such as Martin of Cordoba, John of Wales, Robert Basevorn or Ranulf Hidgen, Jacobus lists four reasons for teaching the holy doctrine:

a) the efficient cause (causa efficiens) is divided into two, namely the primary cause (causa principalis), that is, God, who is the first agent that inspired the writing of the sermon, and the instrumental cause (causa instrumentalis), that is, the preacher, whose "mouth is moved by God"; 24

23 F. Morenzoni, "La littérature des artes praedicandi de la fin du XIIe au début du XVe siècle”, in Geschichte der Sprachtheorie, Hrsg. von P. Schmitter, Bd. 3, Sprachtheorien in Spätantike und Mittelalter, Hrsg. von S. Ebbesen, Tübingen 1995, p. 349.

24 "In this way the sermon is inscribed in the circle of the mysticism of the word, where the transmission of the message takes place in an invisible, but audible 
b) the formal cause (causa formalis) - concerns the abundance of comparisons, authorities, examples and evidence that a preacher must use;

c) the material cause (causa materialis) - expressed in the words in scientia et in omni sensu from the biblical opening quotation; concerns the knowledge contained in the Scriptures and the ability to interpret all of its senses;

d) final cause (causa finalis) - concerns practising virtues and avoiding sins because preaching is to lead to the implementation of such an attitude.

In the following chapters, Jacobus discusses subsequent parts of a sermon (thema, prothema, divisio, subdivisio) and the ways in which its content may be presented, where he lists twelve such manners: a) with the help of concordant authorities; b) by discussing words; c) by multiplying the meanings or explanations [of words]; d) by interpreting or describing a name; $;^{25}$ e) by comparisons and various compound words; f) by multiplying synonyms; $g$ ) with the help of the properties of things; h) by similitudes; i) by indicating the opposite; j) by dividing a whole into its parts; k) by considering or indicating

way from God himself, the spirit, through the ears, that is the gateways of the body, directly to the soul of the faithful" - he notes, pondering the status of the preacher as a medium between the Creator and the faithful, Krzysztof Bracha (Bracha, Nauczanie, p. 106).

${ }^{25}$ The central point of Jacobus' deliberations is the theory of senses (noemata), or rather the types of biblical exegesis or, in a broader sense, the issues of hermeneutics. The Creator is presented here as the author of a double-meaning book, and the intentio auctoris becomes the intention of God. Detailed exegetical techniques make it possible to discover this intention, i.e. the reconstructive interpretation imperceptibly becomes a creative one. More on the biblical exegesis and the theory of four senses-cf. the fundamental work by $\mathrm{H}$. de Lubac, Exégèse médiévale : les quatre sens de l'Écriture, Paris 1959-1964, and also D. S. Ferguson, Biblical Hermeneutics: An Intruduction, 1986; R. N. Longenecker, Biblical Exegesis in the Apostolic Period, Ed. $2^{\text {nd }}, 1$ 1999; Biblical Interpretation. History, Context, and Reality, ed. C. Helmer and T. G. Petrey, Symposium Series (Society of Biblical Literature), No. 26, 2005. 
causes and effects; 1) by reasoning. ${ }^{26}$ Most of the solutions proposed by Jacobus are not original. He often repeats the established definitions but sometimes narrows down their understanding or changes their meaning slightly.

(b) Tractatulus solennis de arte et vero modo predicandi by Pseudo-Thomas Aquinas

This treatise draws abundantly from the work of Jacobus de Fusignano. Until recently, there was controversy among researchers about which treatise was the first, but it was eventually established that the anonymous Dominican used the work of his fellow brother. Researchers initially assumed that it might have actually been written by Henry of Hessen, while the title attributes the work to Thomas Aquinas. ${ }^{27}$ The current state of knowledge only allows us to establish that it was authored by Pseudo-Thomas Aquinas and that it was written later than Jacobus's textbook.

The small text contains a definition of preaching ("open and public advice on faith and morals" ${ }^{28}$ ), recommendations on the style of preaching (the preferred style was emotional, full of enthusiasm, with rhetorical questions, elements of horror and irony) and the mistakes of the preacher (faults in a sermon include the ignorance of the preacher, his lack of fluency, excessive noisiness, sleepy delivery, finger-pointing, tossing of his head, and remote digression ${ }^{29}$ ). He also lists and discusses nine ways of building a sermon: (a) using authority, (b) considering words, (c) qualities of things, (d) variety of senses, (e) natural similarities and truths, (f) pointing out opposites, (g) comparisons, (h) interpreting names, and (i) multiplying synonyms. Then the treatise

26 Jacobus de Fusignano, Libellus artis praedicatorie, in Wenzel, The Art, pp. 39-41.

27 T. M. Charland, Artes Praedicandi. Contribution à l'histoire de la rhétorique au moyen âge, Paris 1936, p. 87.

28 Caplan, "A late mediaeval", p. 55.

29 Ibid., p. 58. 
ends and is followed by an explanation of why the sermon resembles a tree, as well as a reference to an attached drawing.

The output of Mikołaj of Błonie ${ }^{30}$ (c. 1400-1448), a doctor of decrees, includes not only sermons on Sundays and holidays (gathered in two collections: de tempore and de sanctis), but also an extremely widely read treatise on sacraments, as well as poetic works. During his studies in Cracow, Pszczółka came into contact with the then Polish intellectual elite. He attended lectures given by the most eminent minds of the epoch, such as Stanisław of Skarbimierz, Paweł Włodkowic, or Franciszek of Brzeg. In 1428, Stanisław Ciołek was consecrated as the Bishop of Poznań, and a year later Pszczółka moved to Poznań, where he became the chaplain of the new bishop and-probablypreached in the Poznan cathedral. On 1 September 1433, he was appointed Prosecutor of the Council of Basel as the representative of the Poznań Chapter. It is not known whether or not he finally went to Basel. After Ciołek's death, Pszczółka returned to his homeland, Mazovia. The parish priest in Czersk, the Canon of the cathedral in Płock, the Canon of Warsaw, and in the years 1439-1441 the Warsaw Official with the seat at the college of St Stanislaus - performing these functions, Pszczółka worked in the office of Mazovian Dukes and in the district chancellery [kancelaria ziemska]. Since 1442, his health deteriorated, so he asked the Warsaw Vicar Filip to hold worship

30 More important studies on the life and work of Mikołaj of Błonie: B. Ulanowski, "Mikołaj z Błonia, kanonista polski pierwszej połowy XV w., Rozprawy AU. Wydział Historyczno-Filozoficzny 23 (1888); M. Zwiercan, "Mikołaj z Błonia”, in Polski słownik biograficzny, Wrocław 1976, pp. 102-104; M. Zahajkiewicz, „Tractatus sacerdotalis" Mikołaja z Błonia na tle teologii przełomu XIV i XV wieku, Lublin 1979; T. Szostek, "Exempla i autorytety w kazaniach Jakuba z Paradyża i Mikołaja z Błonia”, in Kultura elitarna i kultura masowa, ed. B. Geremek, Wrocław 1978, pp. 291-308; T. Szostek, Exemplum w polskim średniowieczu, Warsaw 1997; K. Panuś, Zarys historii kaznodziejstwa w Kościele katolickim, part 2: Kaznodziejstwo w Polsce od średniowiecza do baroku, Cracow 2001. 
services for his soul in exchange for books offered to the Warsaw vicars. He died before 1448 .

Scholars do not agree on when Pszczółka delivered and wrote his sermons. One of them mentions the year 1438, but it does not prove that the texts were written in that year. As Father Jerzy Wolny claimed, the collection of de tempore sermons "was probably created in Cracow and from here, distributed by German students, it reached southern Germany, where thanks to its literary values and usefulness in preaching it found recognition among German printers. The collection of de sanctis sermons was created in Poznań" ${ }^{31}$ On the other hand, Bronisław Geremek expressed his conviction that Pszczółka’s sermons were indeed written in Czersk in that very year. One thing is beyond doubt - the two collections by Mikołaj of Błonie were conceived as standard sermons, supposed to serve as model examples of the implementation of the preaching art and as a textbook for other preachers who could use selected texts and modify them freely.

Due to the genre specificity of sermons and considering the purpose of Pszczółka's predicatory output, we will not find in his speeches direct evidence that he read the treatises of Jacobus de Fusignano and Pseudo-Thomas Aquinas. Nonetheless, the hypothesis that he knew at least the principles laid out in Jacobus's textbook is supported by several facts: the Libellus artis praedicatorie treatise was kept in Polish libraries, it has been shown that the work was known to the Italian Dominican Stanisław of Skarbimierz, who had a great influence on the work of Mikołaj of Błonie, ${ }^{32}$ and the predicatory practice of the latter was convergent with some rules proposed by Jacobus de Fusignano and Pseudo-Thomas Aquinas.

When considering textbooks of ars predicandi and Polish mediaeval preaching, one should bear in mind certain assumptions. The

31 J. Wolny, Recenzja rozprawy doktorskiej dr Teresy Szostek, s. 3. (T. Szostek, Egzempla w kazaniach de tempore Jakuba $z$ Paradyża i Mikołaja z Błonia, 25/01/1984, Instytut Badań Literackich PAN).

32 Chmielowska, "Ars praedicandi". 
art of preaching was studied in at least four ways: at the university (by practising speeches), in pastoral practise (especially in the lower clergy), by reading collections of sermons and textbooks on preaching, and by listening to sermons. Pszczółka’s preaching was also influenced by these factors. First of all, he learned to give speeches as a student at the University of Cracow, where he began his education in 1414. Although the chair of rhetoric, supported by the foundation of Katarzyna Mężykowa, did not begin its activity until the 1420s, from the very beginning, the art of elocution and the art of arranging public statements were taught as part of the curriculum of the liberal arts. Secondly, from around 1422, Pszczółka held the office of a preacher to Queen Sophia of Halshany. Thirdly, during his studies, he came into contact with outstanding orators of his times, including Stanisław of Skarbimierz and Franciszek of Brzeg, whom he held in particular esteem. Fourthly, while in Cracow, he could use preaching textbooks, including the treatise by Jacobus. Therefore, it is worth taking a closer look at what Jacobus de Fusignano and Pseudo-Thomas Aquinas said about arbor picta and how this theory is reflected in the preaching practice of Mikołaj of Błonie.

In the treatise of Jacobus, we come across the following fragment:

Sciendum quoque est quod praedicatio videtur arbori simulari. Arbor enim cum ex radice in truncum conscenderit et truncus in principales ramos pululaverit, adhuc ipsi principales rami in alios secundarios multiplicantur, sic et praedicatio, postquam ex themate in prelocutionem processerit, tanquam in radice in truncum, ac deinde ex prelocutione in principalem divisionem thematis tanquam in ramos principales, debet ulterius per secundarias distinciones multiplicari. ${ }^{33}$

[We must also know that a sermon can be likened to a tree. For as a tree rises from its root to its trunk, and its trunk divides into the main branches,

33 Jacobus de Fusignano, Libellus, p. 36. 
and these main branches further multiply into secondary ones, thus the sermon, after it has proceeded from the thema to the preamble, as if from its root into the trunk, and then from the preamble into the main division of the thema, as if to the main branches, it must be further multiplied with the help of secondary distinctions. ${ }^{34}$ ]

In the given fragment, there is a precisely presented comparison (similitudo) of a sermon to a tree. The trunk of the tree grows from its roots, while the main branches grow from the trunk and are later divided into smaller branches. Similarly, the prelocutio (trunk) is to grow from the theme (roots), while from the main branches (divisio) further detailed subdivisions, or ways of amplification are to stem. Continuing this comparison, Jacobus ${ }^{35}$ writes:

Ut autem similitudinem sermonis ad arborem prosequamur, considerandum est quod sicut arbor postquam in secundarios ramos germinaverit, adhuc per ramusculos dilatatur, sic et praedicatio non debet sistere in sola divisione thematis et subdivisione membrorum, sed oportet ipsam ulterius dilatari, ut decendi modo texatur. ${ }^{36}$

[Continuing our comparison of a sermon to a tree, we must consider that, just as a tree, after it has sprouted secondary branches, still expands through twigs, so a sermon must not rest with the division of the thema and the subdivision of its parts alone, but must have it expanded further so that it is built up in a proper way. $\left.{ }^{37}\right]$

He, therefore, draws attention to the need for detailed thought, deepening of threads, and careful analysis. He stresses that just as

34 Ibid., p. 37.

35 In her research, Dorothea Roth (Die mittelalterliche Predigttheorie, p. 101) did not come across a comparison of a sermon to a tree earlier than Fusignano's treatise, and Otto A. Dieter ("Arbor Picta", p. 131) stressed that certainly treatises on preaching, in which visual patterns of sermons appeared, were secondary to practice.

36 Jacobus de Fusignano, Libellus, p. 38.

37 Ibid., p. 39. 
a tree grows into smaller twigs after the branches have sprouted, so the sermon cannot stop at divisio and subdivisio, but must develop (dilatatio), i.e. explore the full potential of a theme by using various amplification techniques, which Fusignano discussed in detail later in his textbook.

Giacomo's assumptions were repeated by Pseudo-Thomas Aquinas, who added that the theme of the sermon should be divided into three basic partes, which in turn should be divided into three smaller subdivisiones. These should be explained by means of several amplifying methods, which Pseudo-Thomas enumerated in a way similar to those presented in Jacobus's textbook. The treatise in Caplan's edition is accompanied by a print, Arbor de arte sive modo praedicandi, which specifies exactly the position of each element of the sermon and the principles of the division (partitio) of its theme and structure (dispositio).

These strict rules concerning the divisio of sermons were used by Mikołaj of Błonie in most of his speeches. Let us investigate this in an example. In the de tempore ${ }^{38}$ collection, Pszczółka contained three sermons for the second Sunday of Shrovetide, called Sexagesima, connected with the evangelical pericope concerning the word of God as a seed. I am interested in sermo $39^{39}$ entitled Semen est verbum Dei (Fig. 1). According to the recommendations of Pseudo-Thomas Aquinas, Pszczółka divided the verbum thematis into three parts: 1) The Word of God, 2) is, 3) as a seed, devoting unequal attention to each of these parts. He elaborately composed a few levels of explanation of what it means in the Gospel that the Word of God is a seed. ${ }^{40}$ Pszczółka creatively used the ways of building a sermon proposed by

38 Mikołaj of Błonie, Sermones venerabilis magistri Nicolai de Blony . . . de tempore et de sanctis, Strasbourg 1498.

39 Mikołaj of Błonie, Dominica sexagesime: sermo 39 „Semen est verbum Dei”, ff. $\mathrm{q} 1 \mathrm{r}-\mathrm{q} 4 \mathrm{r}$ (pagination includes the jacket).

40 The analysis of the metaphor of seed as the Word of God in the context of late mediaeval preaching is presented in a paper by Krzysztof Bracha, "Semen est verbum Dei. Postylla Carcer animae przypisywana Janowi Szczeknie”, in 
Jacobus. Each of the words on the subject receives additional explanations, which revolve around the main assumption.

Pszczółka first explained what was associated with the concept that the Word of God $(1, v e r b u m$ Dei) is a seed. Firstly, for the Word of God to grow like a seed, water is needed (1a, aqua). Its qualities and activities such as easy current (1aa, facilitas), moisturisation/ watering (1ab, humectatio), clarity and perspicacity (1ac, claritas et perspicacitas) are explained in the moralist and theological key so that this comparison acquires a tropological and anagogical sense. In a similar way, he develops the next parts of the sermon.

The Word of God, like the seed, is used to make bread (1b, panis), which symbolises spiritual food. Preparation (1ba, preparatio) of bread requires undertaking appropriate steps, such as shaking the grain from the straw, grinding it with a millstone and baking bread from the flour thus produced. Similarly, the preparation of the Word of God requires the spiritual purgation of the preacher, the repentance obtained through pious meditation and the fire of the Holy Spirit. This comparison is based on three expressions: palea (1baa), contritio (1bab), and ignis (1bac). The Word of God can also be called bread because it is an egalitarian meal (1bbb) for both the poor (uneducated) and the rich (learned), although it can be served in different ways and in different quantities. Another characteristic that legitimises comparing the Word of God to bread is the latter's nutritious value (lbc). Bread invigorates the physical strength of man, while the Word of God strengthens the mental power (quia panis operatur sanitatem, vires et robur fortitudinis auget, et ne homo deficiat, sustentat. Sic panis verbi Dei operatur sanitatem mentis).

The Word of God sprouts from a seed (1c, semen), which is taken into a hand (1ca, the hands are our deeds-manus enim nostrae opera nostrae sunt) and sown not in one place but all around the field (1cb, therefore the Gospel should be proclaimed to the whole world-beati

Amoenitates vel lepores philologiae, ed. R. Laskowski and R. Mazurkiewicz, Cracow 2007, pp. 61-71. 
qui praedicatis evangelium omni creaturae), and which should be sown at the right time (1cc, the preacher must know when to remain silent and when to speak; Pszczółka refers here to the maxim from Cura pastoralis by Pope Gregor I: the praedicator debet esse discretus in silentio, utilis in verbo, ne aut tacenda proferat, aut proferenda retices$c a t)$, is to yield the crop $(1 \mathrm{~cd}$, the farmer's effort is rewarded with the crop, the preacher's reward is merces aeterna-the eternal payment).

The next word analysed is the verb 'is' $(2$, verbum substantiale "est"). We learn that the Word of God is a cure for the soul (2a, est animae sanativum), the clarity of mind and passion ( $2 \mathrm{~b}$, est animae illuminantivum et inflamantivum), and gives one eternal life (2c, est vitae et gloriae donativum).

Most attention is paid to explaining the comparison of the Word of God to a seed (3). Mikołaj of Błonie attempted to present seven obstacles that prevented the Word of God from growing in the mind of man. These obstacles are calculated on the basis of a slightly modified list of deadly sins:

3a. Trampling (conculcatio, which refers to debauchery, luxuria). A man can "trample" the bride of Christ (3aa, sponsa Christi), the person of Christ (3ab, persona Christi), and the words of Christ (3ac, verba Christi). Pszczółka emphasises that for the bride (3aaa), Christ descended from heaven (3aaa, descendit a supremo coelo), worked for thirty-three years (3aab, multos labores triginta tres annos sustinuit), and died a cruel death (3aac, mortem duram subiit). The person of Christ (3aba) is trampled by those who persist in a deadly $\sin$ (3aba, quando in peccato mortali summitur et in foetidum cor mittitur), perjurers (3abb a periurantibus), and people engaged in witchcraft (3abc, per incantationes). The words of Christ (3ac) are disregarded by ignoring the admonitions of preachers (3aca, propter duram reprehensionem culpatum), defying the threats of hellish torments (3acb, propter asperam comminationem), and neglecting the unshakable truth (3acc, propter assertionem veritatis);

3b. Rainfall deficit and dryness of the earth (pluviae carentia et terrae siccitas), or impiousness (indevotio), which is associated with sloth (acedia); 
3c. Overgrowing by thorns and spikes (spinarum suffocatio), that is wealth (divitiae), which stings like thorns (spinae sunt divitiae) because it grows thanks to someone else's work (3ca, pungunt in acquirendo cum labore), exercises power based on fear ( $3 \mathrm{cb}$, cum timore possidentur), results in suffering (3cc, cum dolore perduntur);

3d. Incorrect storage (clausurae defectus) or pride (superbia);

3e. Sowing too deep (nimis profunda plantatio grani in terra), i.e. greed (avaritia);

3f. Excessive irrigation (nimia inundatio pluviae), i.e. gluttony (gula);

3g. Stony soil (lapidum cumulatio nimia), i.e. anger and envy (ira, invidia).

As the above list shows, Pszczółka tried to maintain the triple division of the argument advocated by Jacobus and Pseudo-Thomas. ${ }^{41}$ The basis of his argument is the evangelical pericope, which develops into successive branches (subdivisiones). Now, it is time to look at what the use of arbor picta in a sermon could serve.

The use of a tree scheme to build a sermon may have aided the preachers' work on many levels. It is quite obvious that such a structure aided in memorising the text of the sermons, which were often preached from memory. In addition, it systematised the issues raised and taught the precision and consistency of the argument. Since the tree scheme is based on causal chains, relationships and enumerations, it is not difficult to notice that it imitated scholastic treatises. The metaphorical value of praedicandi arbor was not without significance either. It indicated the organic character of the text and thus the organic and natural character of divine laws.

41 The triple division of any discussion or explicating a topic along three lines is also part of the scholastic style of argumentation. 


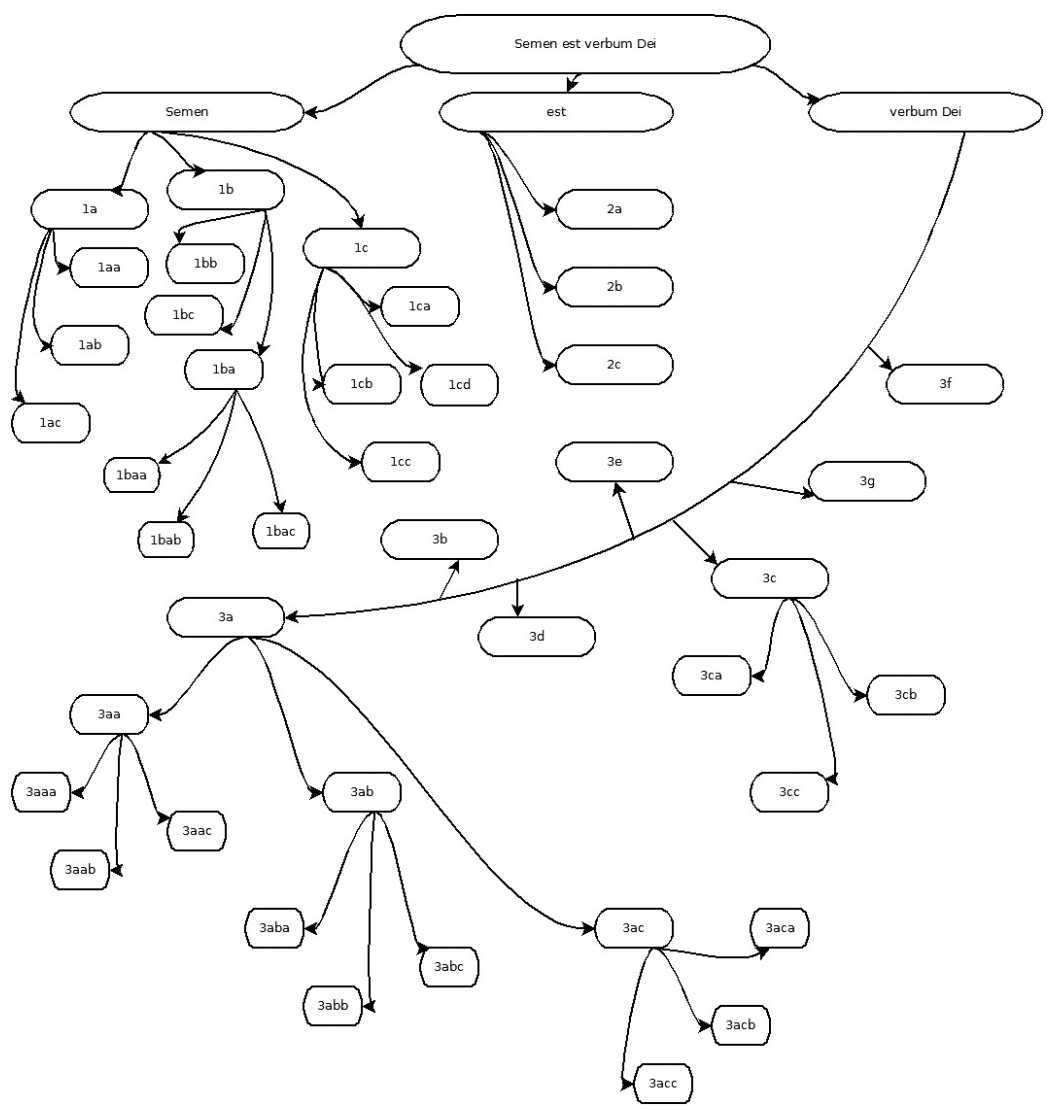

Memoria as the fourth part (pars) of rhetoric included memorising techniques (based on Cicero's permanent retaining of content and words in one's mind $^{42}$ ) and the theory of memory ${ }^{43}$ The work on memory improvement took the form of a separate art (ars memorativa), which became a subject of careful interest of mediaeval thinkers

42 M. T. Cicero, O inwencji retorycznej. De inventione, transl. by K. Ekes, Warsaw 2013, pp. 32-33.

43 Michałowska, Średniowieczna, p. 183. 
and theoreticians of literature. Artificial memory, or artificiosa memoria, i.e. the one we practise in the course of learning, was based on places (loci) and images (imagines, simulacra) connected with the outside world. ${ }^{44}$ "So let art imitate nature, find what it demands and follow its instructions", ${ }^{45}$ said the anonymous author of the textbook Rhetorica ad Herennium, widely read in the Middle Ages. In De memoria et reminiscentia commentarium, Saint Thomas emphasised that reason uses the available images of material things to capture abstraction and universals. ${ }^{46}$ And Ramon Llull, mentioned above, proposed not so much the use of imagery as diagrams in the form of trees, which allow for a schematic representation of common places (loci communes). ${ }^{47}$ Inscribing the issues raised in the sermon into the tree diagram made it easier to remember the sermon and prevented the threat of omitting any important information. Alastair Minnis pointed out that this kind of mnemonics was useful not only to the preachers themselves, but also to the listeners. ${ }^{48}$ Mary Carruthers emphasised that each of these mediaeval diagrams is not a finished entity but rather encourages the reader to recompose the initial scheme. ${ }^{49}$ This encouragement may be addressed to the next author of the text, in this case, to a preacher, who will use the prepared model sermon. Although Jacobus de Fusignano and Pseudo-Thomas Aquinas did not explicitly combine the tree model they proposed with the art

44 F. A. Yates, “The art of memory", in: F. A. Yates, Selected Works, vol. 3, New York 1999, pp. 6-16.

45 Rhetorica ad Herennium, as cited in: Yates, “The art”, p. 22.

46 Ibid., p. 82; cf. Thomas Aquinas, O pamięci i przypominaniu, transl. M. Zembrzuski, Warsaw 2012.

47 Ibid., pp. 179-199.

48 Minnis, "Medieval imagination", p. 272. Cf. also D. van der Poel, "Memorabele bomen: De minneboom als allegorische constructie in de Middelnederlandse wereldlijke letterkunde", in Aan de vruchten kent men de boom: De boom in tekst en beeld in de middeleeuwse Nederlanden, ed. B. Baert and V. Fraeters, Symbolae Falcultatis Litterarum Lovaniensis Series B, Leuwen 2001, pp. 239-259.

49 M. Carruthers, The Book of Memory. A Study of Memory in Medieval Culture, Cambridge 1990, p. 123. 
of memorising, it is nevertheless clear, especially if we consider the example of Mikołaj of Błonie's sermon discussed earlier, that giving sermons a tree scheme with an explicated central idea (thema) had a practical dimension and served, among other things, the purpose of faster and more effective assimilation of information, both by the clergyman and his listeners. ${ }^{50}$ It should also be remembered that Pszczółka's collection was written down as a model collection, a syllabus for preachers. If the dispositio of sermons was logical, coherent and interconnected, it was easier for the audience to understand the truths of faith, remember them, and then correctly convey them. ${ }^{51}$

The tree diagram also allowed for the hierarchisation of issues. The mediaeval works mentioned at the beginning of this paper that systematise, e.g. the division of arts and sciences, were aimed at arranging the fields of knowledge in accordance with how they were valued. In the case of sermons, the hierarchy of thoughts is also evident. Fusignano emphasised that a sermon should be based on a theme from which the preacher is to draw inspiration for the most accurate explanation. However, let us consider the diagram that can be drawn on the basis of Mikołaj of Błonie's sermon (Fig. 1). It is clear that not all boughs and branches are of the same size. Pszczółka devoted most attention to the central theme of the Word of God, thus giving greater importance to one of the subdivisiones. He, therefore,

50 Sermons taught the basic truths of faith, such as the Ten Commandments, the eight blessings, the gifts of the Holy Spirit, etc., thus forming part of pastoral education, according to the Council's principles of cura animarum. In this respect, Pszczółka's sermons can be treated as an extension and supplementation of theological knowledge, especially moralistic knowledge, which he included in the textbook for the clergy entitled Tractatus sacerdotalis. More about memorial techniques in the context of teaching about virtues and sins: K. A. Rivers, Preaching the Memory of Virtue and Vice: Memory, Images, and Preaching in the Late Middle Ages, Turnhout 2010.

51 Correctly, that is, orthodoxly, because the uneducated preachers, having erroneously remembered the reasoning from the model sermon, could pass on poor theological knowledge. The art of remembrance was the guardian of the correctness of the explicated dogmas and principles of faith. 
hierarchised the constituent elements of the theme, showing which are more important and which require more attention from the audience.

The sermon structured according to the tree diagram fits well in the so-called natural rhetoric. ${ }^{52}$ It is organic, develops naturally, conforms with nature, and therefore it is divine. Such organisation of text seems to be sophisticated and artificial, but in fact the comparison is to make us realise that the sermon is an element of nature. The outside world that enters into the consciousness of man with all his or her senses is chaos, so if the man does not want to get lost in it, he or she thinks up perfectly clear categories, gives every part of reality some meaning and places it in relation to other elements. Arranging the world in order is not so much an attempt to understand the rules as to define them. Language, according to Yuri Lotman's theory, becomes the power that organises the world..$^{53}$ Mikołaj of Błonie's sermon, quoted as an example, was an attempt to combine the Biblical language with a strictly logical and coherent lecture, a system of relations and dependencies, a cause and effect, a result. By giving his argument the structure of a tree, he somehow reconstructed the ordered complexity of the world in which every element has its place and does not function all alone, but is one of the rungs (one of the branches), being at the same time the starting point and the destination, the cause and the effect.

Particular attention in the construction of the sermon was also paid to the repetitiveness of formulas, enumerations, and the discipline of thought. Apart from the purely practical dimension, i.e. the mnemonic one, the hermeneutical dimension is here manifested, and the necessity of explanation becomes the basic need and the basic dimension of human life. Pszczółka, expressing his thoughts on the subject of Semen est verbum Dei by way of the cognitive scheme of

52 M. D. Johnson, "The natural rhetoric of Ramon Llull", Essays in Medieval Studies 3 (1986), pp. 174-191.

53 J. Łotman, Uniwersum umysłu. Semiotyczna teoria kultury, transl. B. Żyłko, Gdańsk 2008. 
a tree, performed a double operation of making and explaining the metaphor, which actually becomes a record of the process of understanding. Hans-Georg Gadamer claimed that the world is perceived by every human being in a way in which it does not appear to any other creature. Indeed, a sermon is an attempt to explain the world, the Gospel and the principles of faith in accordance with rhetorical rules and biblical exegesis, as well as in a way comprehensible for the audience. Therefore, among the many mediaeval sermons built around the same verba thematis we will not find two similar explanations. Thanks to metaphors and symbols, semiotics, which consists in constant references of signs to signs, leads to ever-changing interpretations. It is the way to create and maintain a community, to create culture and interpret it in limitless ways. The tree-like sermon scheme becomes a framework that the preacher updates, giving it a unique character. And just as there are no two identical trees, there are no two identical sermons.

Both in theoretical deliberations on the art of preaching and in practical implementations of the recommendations on the subject, the tree scheme was used to present abstract concepts or to structure the text. The use of such a tree image made it possible to visualise abstract concepts and to show their mutual relations. Using a tree diagram helped to elaborate a thought or idea and made it easier to remember the educational content. ${ }^{54}$ Such a structure of a sermon had not only an epistemological status (it allowed cognition), but also an ontological one (it allowed the listeners to find themselves and define their place in the world, that is to recognise that they belonged to the world). With regard to the symbolic dimension, the use of this scheme in mediaeval preaching had deep philosophical substantiation (the tree of life, the tree of the cross, the tree as an element

${ }^{54}$ Poel, "Memorabele bomen". 
of nature, the tree as a symbol of hierarchy). Moreover, mediaeval sermons had a highly organised form, so the structure of the tree as a proposed type of dispositio that carries many additional meanings was very popular. The sermon of Pszczółka, discussed above, shows that it was a kind of scholastic-organic divisio of the text, taken from proposed models proposed by, amongst others, Jacobus de Fusignano and Pseudo-Thomas Aquinas, indicates an interesting current in Polish mediaeval preaching and gives an inducement for further research and analyses within this area.

Translated from Polish by Kaja Szymańska

\section{Bibliography}

Anderson F. D., "Dispositio in the preaching of Hugh Latimer", Speech Monographs 35 (1968).

Biblical Interpretation. History, Context, and Reality, ed. C. Helmer and T. G. Petrey, Symposium Series (Society of Biblical Literature), No. 26, 2005.

Бондарко Н. А., “Трактат о пальме. Композиционная форма и богословский смысл”, Начало. Журнал института богословия и философии 9 (2000).

Bonner P. A., The Art and Logic of Ramon Llull, Brill 2007.

Bracha K., Nauczanie kaznodziejskie w Polsce późnego średniowiecza. „Sermones dominicales et festivales" $z$ tzw. kolekcji Piotra $z$ Miłosławia, Kielce 2007.

Bracha K., "Semen est verbum Dei. Postylla Carcer animae przypisywana Janowi Szczeknie", in Amoenitates vel lepores philologiae, ed. R. Laskowski and R. Mazurkiewicz, Cracow 2007.

Caplan H., "A late mediaeval tractate on preaching", in H. Caplan, Of Eloquence. Studies in Ancient and Mediaeval Rhetoric, 1970.

Carruthers M., The Book of Memory. A Study of Memory in Medieval Culture, Cambridge 1990.

Catalogus codicum latinorum Bibliothecae Regiae Monacensis, ed. C. Halm and G. Meyer, vol. 4, part 4, Munich 1881, http://daten.digitalesammlungen.de/ db/ bsb00008255/images/index.html?fip $=193.174 .98 .30 \&$ seite $=109 \& p d f s e i t e x=($ accessed on 7 June 2014).

Charland T. M., Artes Praedicandi. Contribution à l'histoire de la rhétorique au moyen âge, Paris 1936. 
Chmielowska B., "Ars praedicandi Stanisława ze Skarbimierza", in Retoryka w XV stuleciu. Studia nad tradycjami, teoriq i praktyka retoryki piętnastowiecznej, ed. M. Frankowska-Terlecka, Wrocław 1988.

Cicero M. T., O inwencji retorycznej. De inventione, transl. K. Ekes, Warsaw 2013.

Dieter O. A., "Arbor Picta. The medieval tree of preaching", Quarterly Journal of Speech 51 (1965).

Ferguson D. S., Biblical Hermeneutics: An Intruduction, 1986.

Flor F. R. de la, "El diagrama: geometría y lógica en la literatura espiritual del Siglo de Oro", in Estado actual de los estudios sobre el Siglo de Oro, ed. M. García Martín, Salamanca 1983.

Hallik S., Sententia und proverbium, Begriffsgeschichte und Texttheorie in Antike und Mittelalter, Köln 2007.

James E. O., "The tree of life, studies in the history of religions", Supplements to Numen 11 (1966).

Johnson M. D., "The natural rhetoric of Ramon Llull”, Essays in Medieval Studies 3 (1986).

Käpelli T., "Jacobus de Fusignano OP ( $† 1333)$ ”, Archivum Fratrum Praedicatorum 15 (1945).

Khan S., Diversa Diversis. Mittelalterliche Standespredigten Und Ihre Visualisierung, Köln 2007.

Klapish Zuber C., "The tree", in Finding Europe: Discourses on Margins, Communities, Images Ca. $13^{\text {th }}-\mathrm{Ca}$. $18^{\text {th }}$ Centuries, ed. A. Molho, D. Ramada Curto, and N. Koniordos, Oxford-New York 2007.

Longenecker R. N., Biblical Exegesis in the Apostolic Period, Ed. $2^{\text {nd }}, 1999$.

Los Mundos de Ramón Llull, ed. J. Butiñá Jiménez, Madrid 2012.

Lubac de H., Exégèse médiévale : les quatre sens de l'Écriture, Paris 1959-1964.

Łotman J., Uniwersum umystu. Semiotyczna teoria kultury, transl. B. Żyłko, Gdańsk 2008.

Michałowska T., Średniowieczna teoria literatury w Polsce. Rekonesans, Wrocław 2007.

Mikołaj of Błonie, Sermones venerabilis magistri Nicolai de Blony . . . de tempore et de sanctis, Strasbourg 1498.

Minnis A., "Medieval imagination and memory", in The Cambridge History of Literary Criticism, vol. 2: Middle Ages, ed. A. Minnis and I. Johnson, Cambridge 2005.

Morenzoni F., "La littérature des artes praedicandi de la fin du XIIe au début du XVe siècle", in Geschichte der Sprachtheorie, Hrsg. von P. Schmitter, Bd. 3, Sprachtheorien in Spätantike und Mittelalter, Hrsg. von S. Ebbesen, Tübingen 1995.

O'Connell P. F., The "Lignum Vitae" of Saint Bonaventure and the Medieval Devotional Tradition (Spirituality, Franciscans), ETD Collection for Fordham University, 1985.

Panuś K., Zarys historii kaznodziejstwa w Kościele Katolickim, part 2: Kaznodziejstwo w Polsce od średniowiecza do baroku, Cracow 2001.

Pastor J. P., "La mística Luliana : pretensión de síntesis", Taula: quaderns de pensament 37 (2002). 
Poel D. van der, "Memorabele bomen: De minneboom als allegorische constructie in de Middelnederlandse wereldlijke letterkunde", in Aan de vruchten kent men de boom: De boom in tekst en beeld in de middeleeuwse Nederlanden, ed. B. Baert and V. Fraeters, Symbolae Falcultatis Litterarum Lovaniensis Series B, Leuwen 2001.

Pussman K., "Historia barzo cudna o stworzeniu nieba i ziemie", in Cały świat nie pomieściłby ksiąg. Staropolskie opowieści i przekazy apokryficzne, ed. W. R. Rzepka and W. Wydra, Ed. $2^{\text {nd }}$, Warsaw 2008.

Rivers K. A., Preaching the Memory of Virtue and Vice: Memory, Images, and Preaching in the Late Middle Ages, Turnhout 2010.

Robinson C., "Trees of love, trees of knowledge: Toward the definition of a crossconfessional current in late medieval Iberian spirituality, Medieval Encounters 3 (2006).

Roth D., Die mittelalterliche Predigttheorie und das Manuale Curatorum des Johann Urlich Surgant, Basle 1956.

Ruiz Simón M., L’Art de Raimundo Lulio i la teoría escolàstica de la ciència, Barcelona 1999.

Smith N., Smith P. L. R., and Luckett H., "The tree in world mythologies", in The Tree of Life: New Images of an Ancient Symbol, London 1989.

Stenck N. H., "A late medieval arbor scientiarum", Speculum 2/50 (1975).

Szostek T., "Exempla i autorytety w kazaniach Jakuba z Paradyża i Mikołaja z Błonia", in Kultura elitarna i kultura masowa, ed. B. Geremek, Wrocław 1978.

Szostek T., Exemplum w polskim średniowieczu, Warsaw 1997.

Thomas Aquinas, O pamięci i przypominaniu, transl. M. Zembrzuski, Warsaw 2012.

Ulanowski B., "Mikołaj z Błonia, kanonista polski pierwszej połowy XV w.", Rozprawy AU. Wydział Historyczno-Filozoficzny 23 (1888).

Verboon A. R., Lines of Thoughts: Diagrammatic Representation and the Scientific Texts of the Arts Faculty 1200-1500, Univeristeit Leiden 2010 (doctoral thesis).

Wenzel G. S., The Art of Preaching. Five Medieval Texts and Translations, Washington D.C. 2013.

Widengren G., The King and the Tree of Life in Ancient Near Eastern Religion, Uppsala 1951.

Wolny J., Recenzja rozprawy doktorskiej dr Teresy Szostek, s. 3. (T. Szostek, Egzempla w kazaniach de tempore Jakuba z Paradyża i Mikołaja z Błonia, 25/01/1984, Instytut Badań Literackich PAN).

Yates F. A., "The art of memory", in: F. A. Yates, Selected Works, vol. 3, New York 1999. Zahajkiewicz M., „Tractatus sacerdotalis” Mikołaja z Błonia na tle teologii przełomu XIV i XV wieku, Lublin 1979.

Zawadzki R. M., Spuścizna pisarska Stanisława ze Skarbimierza. Studium źródłoznawcze, Cracow 1979.

Zwiercan M., "Mikołaj z Błonia", in Polski słownik biograficzny, Wrocław 1976.

www.ramonllull.net (accessed on 16 Feb. 2014).

www.quiestllullus.narpan.net (accessed on 1 Feb. 2014). 